Jurnal Manajemen dan Bisnis MEDIA EKONOMI, Vol. XIX, No. 2 Juli 2019

\title{
PENGARUH TURUNNYA HARGA LADA TERHADAP PEREKONOMIAN MASYARAKAT DESA BENCAH BANGKA BELITUNG
}

\author{
Aprilia Maharani ${ }^{1}$ \\ Manajemen,Fakultas Ekonomi,Universitas Bangka Belitung \\ email : aprilia.maharani2015@gmail.com \\ Sumiyanti ${ }^{2}$ \\ Manajemen,Fakultas Ekonomi,Universitas Bangka Belitung \\ e-mail : sumiyanti063@gmail.com
}

\begin{abstract}
Abstrak
Penelitian ini adalah studi kasus pengaruh turunnya harga lada terhadap perekonomian masyarakat Desa Bencah Kepulauan Bangka Belitung. Penelitian ini dilakukan bertujuan untuk mengetahui seberapa besar dampak penurunan harga lada saat ini terhadap pendapatan masyarakat di lokasi penelitian. Penelitian ini dilakukan di Desa Bencah Kecamatan Air Gegas Kabupaten Bangka Selatan Kepulauan Bangka Belitng. Dengan menggunakan data primer dan sekunder. Data primer dilakukan melalui teknik penyebaran kuesioner dengan jumlah responden sebanyak 35 orang yang terpilih dari masyarakat petani, wiraswasta, PNS dan honorer serta data sekunder dilakukan melalui kajian terhadap laporan dan dokumen pihak terkait yang memiliki korelasi dan relevansinya dengan penelitian ini. Selanjutnya dianalisis dengan pendekatan deskriptif dan kualitatif, yaitu melalui penyajian dan penyusunan data kedalam bentuk persentase. Hasil penelitian dan pembahasan diperoleh bahwa 94,6\% masyarakat Desa Bencah merasakan penurunan harga lada saat ini berdampak pada pendapatan mereka. Kisaran penurunan pendapatan yang dirasakan oleh kelompok petani sebesar 70\%-100\% , wiraswasta pendapatannya ikut menurun dalam kisaran $40 \%-70 \%$, sedangkan bagi masyarakat yang bekerja sebagai PNS dan honerer penurunan pendapatan mereka berkisar antara $20 \%-40 \%$. Solusi yang diberikan pemerintah terkait permasalahan dalam penelitian ini adalah program resi gudang lada yang saat ini belum terealisasikan di lokasi penelitian.
\end{abstract}

Kata Kunci : Pendapatan, Harga Lada, Resi Gudang.

\begin{abstract}
Abstrak
This study is a case study of the influence of the decline in pepper prices on the economy of the people of Bencah Village, Bangka Belitung Islands. The research was conducted aimed at finding out how much the impact of the current decline in pepper prices on the income of the people in the study location. Where this research was carried out in Bencah Village,Air Gegas District,South Bangka Regency,Bangka Belitng Islands. By using primary and secondary data. Primary data is done through questionnaire distribution techniques with the number of respondents as many as 35 people selected from the farmers, entrepreneurs, civil servants and honorariums as well as secondary data through a study of related party reports and documents that have a correlation and relevance to this study.Then analyzed by descriptive and qualitative approaches, namely through the presentation and preparation of data in the form of percentages. The results of the study and discussion found that $94.6 \%$ of the village community felt that the decline in pepper prices had an impact on their income. The range of decreases in income perceived by farmer groups is $70 \%-100 \%$, income entrepreneurs are decreasing in the range of $40 \%-70 \%$, while for people who work as civil servants and honerers their income declines range from $20 \%-40 \%$.The solution given by the government regarding the problems in this study is the pepper warehouse receipt prpgram which is currently not realized at the research location.
\end{abstract}

Keywords: Income, Pepper Prices, Warehouse Receipt. 
Jurnal Manajemen dan Bisnis MEDIA EKONOMI, Vol. XIX, No. 2 Juli 2019

\section{PENDAHULUAN}

Indonesia merupakan negara dengan ragam kebudayaan yang beragam serta kepulauan dengan kekayaan sumber daya alam yang sangat melimpah, salah satunya hasil bumi Indonesia yang sangat mendunia adalah rempahrempah. Indonesia memiliki jenis rempah-rempah yang sangat khas dan diminati oleh seluruh dunia, hampir setiap negara mengekspor rempah-rempah yang berasal dari Indonesia. Ada banyak sekali jenis rempah-rempah yang terkenal di Indonesia salah satunya adalah lada. Lada merupakan komoditas perkebunaan Indonesia yang sudah dikenal sejak sebelum masa penjajahan.

Dari berbagai wilayah yang ada di Indonesia sekitar 50 persen lada berasal dari Bangka Belitung sebagai pemasok terbesar. Bangka Belitung memang memiliki perkebunan lada yang sangat luas, bahkan sebagian besar masyarakat di Bangka Belitung bermata pencaharian sebagai petani lada. Namun seiring berjalannya waktu kualitas lada dari Bangka Belitung semakin menurun sehingga menyebabkan harga lada pun cenderung rendah dibandingkan dengan periode sebelumnya. Kita mengetahui bahwa perkebunan lada merupakan salah satu sektor ekonomi dari masyarakat Bangka Belitung terutama wilayah Desa Bencah Bangka Selatan. Kondisi ini menyebabkan pendapatan masyarakat juga melemah, sehingga produktivitas petani lada pun ikut menurun karena harga lada saat ini tidak seimbang dengan biaya produksi yang harus dikeluarkan petani. Selain pada petani, penurunan harga lada juga berpengaruh terhadap pendapatan masyarakat lainnya, misalnya wiraswasta.

Berdasarkan data BPS Bangka Belitung, Ekonomi Kepulauan Bangka Belitung tahun 2018 tumbuh sebesar 4,45 persen, melambat dibandingkan tahun 2017 yang sebesar 4,47 persen. Padahal pihak pemerintah telah menetapkan program resi gudang sebagai salah satu solusi untuk menghindari penurunan harga lada, tetapi sampai saat ini bagi masyarakat Desa Bencah program ini belum menyelesaikan permasalahan yang ada dan kebanyakan petani pun tidak tahu tetang program Resi Gudang. Tujuan dari penelitian ini adalah untuk mengetahui dan menganalisis mengenai pendapatan masyarakat Desa Bencah akibat penurunan harga lada yang menurun drastis baik bagi petani maupun masyarakat dengan jenis pekerjaan lainnya.

\section{RUMUSAN MASALAH}

Dari uraian diatas maka peneliti menembuat sebuah rumusan maslah yaitu seberapa besar pengaruh turunnya harga lada terhadap perekonomian masyarakat Desa Bencah Kepulauan Bangka Belitung.

\section{METODE PENELITIAN}

Populasi adalah kumpulan dari semua kemungkinan orang-orang, benda-benda, dan ukuran lain yang menjadi objek perhatian atau kumpulan seluruh objek yang menjadi perhatian. Sampel adalah suatu bagian dari populasi tertentu yang menjadi perhatian. Dalam penelitian ini, teknik yang digunakan untuk pengampilan sampel adalah sampel acak (Random sampling). Sampel yang digunakan dalam penelitian ini adalah 35 orang dengan persentase $40 \%$ petani, $31,4 \%$ wiraswasta, $11,4 \%$ Honorer, $11,4 \%$ pembeli lada, dan $5.8 \%$ PNS.

Metode yang digunakan dalam penelitian ini adalah dengan menggunakan metode penelitian analisis kualitatif. Metode pengumpulan data dalam penelitian ini adalah metode angket (Kuesioner). Kuesioner merupakan teknik pengumpulan data dengan cara memberi seperangkat pernyataan tertulis kepada responden untuk dijawabnya. Instrumen yang digunakan peneliti untuk mengukur variable penelitian ini adalah menggunakan persentase hasil jawaban responden berupa pilihan dari dua alternatif yaitu setuju dan tidak setuju.

Sumber data yang digunakan dalam penelitian ini ada dua sumber yaitu data primer dan data sekunder. Data primer adalah data yang didapat peneliti dari sumber pertama baik individu atau perseorangan seperti hasil wawancara atau pengisian kuesioner yang biasa dilakukan oleh peneliti. Dalam penelitian ini yang menjadi data primer adalah data yang berkaitan dengan harga lada, kualitas dan lahan lada, pendapatan masyarakat dan kebijakan pemerintah dalam memberikan solusi tentang permasalahan harga untuk lada. Untuk memperoleh data tersebut peneliti menyebarkan kuesioner kepada responden untuk mendapatkan data tersebut.

Data sekunder merupakan data yang diperoleh atau dikumpulkan melalui buku, brosur dan artikel yang didapat dari website yang berkaitan dengan penelitian serta dari pihak kedua. Data sekunder yang peneliti gunakan dalam penelitian ini adalah data dari Kantor Desa Bencah berupa jumlah persentase pekerjaan penduduk desa tersebut. Berdasarkan data tersebut didapatkan bahwa persentase tertinggi penghasilan penduduk Desa Bencah mayoritasnya adalah petani lada yaitu sebanyak 1.871 keluarga yang bekerja sebagai petani lada.

\section{HASIL DAN PEMBAHASAN}

Desa Bencah merupakan desa yang terletak di Kabupaten Bangka Selatan Provinsi Kepulauan Bangka Belitung. Salah satu yang menjadi potensi pendapatan terbesar di desa ini adalah dari sektor pertanian lada. 
Berdasarkan data survei peneliti tercatat sebesar $40 \%$ bekerja sebagai petani lada. Kondisi harga lada saat ini dirasakan oleh masyarkat Desa Bencah semakin menurun dibandingkan dengan tahun-tahun sebelumnya yaitu sebelumnya harga lada pernah mencapai harga sebesar Rp.180.000,00/Kg pada tahun 2016 , Rp. $150.000 / \mathrm{Kg}$ tahun 2017 sedangkan tahun 2018-2019 mulai menurun hingga mencapai kisaran harga Rp.50.000,00/Kg.

Berdasarkan penelitian menunjukkan bahwa sebesar 96,4\% masyarakat merasakan dampak dari penurunan harga lada saat ini mempengaruhi kondisi pendapatan mereka. Penurunan harga lada ini dampaknya tidak hanya dirasakan oleh petani saja tetapi juga oleh masyarakat yang bekerja dibidang selain petani misalnya wiraswasta. Pedagang ikut merasakan bahwa penuruanan pendapatan masyarakat Desa Bencah akibat harga lada yang murah menyebabkan konsumsi masyarakat pun berkurang. Akibatnya, Pedagang merasakan dampak dari penurunan harga lada sebesar 40\%-70\% mempengaruhi pendapatan mereka juga ikut menurun, terutama pedagang makanan, toko baju, serta tengkulak lada ( pembeli lada).

Banyak tanggapan petani mengeluh dikarenakan harga lada saat ini tidak seimbang dengan biaya yang harus dikeluarkan untuk produksi tanaman lada bahkan sebagian petani menyatakan bahwa mereka banyak mendapatkan kegagalan panen sehingga mengalami kerugian yang banyak. Sementara itu, petani juga memiliki kendala ketersediaan lahan untuk bertani lada semakin sedkit yaitu sebesar 62,5\% responden menyatakan bahwa lahan untuk bertani lada saat ini sudah semakin kritis. Dari sisi petani, mereka merasakan penurunan harga yang dratis saat ini memberikan pengaruh yang buruk terhadap pendapatan mereka. Mereka menyatakan bahwa kisaran antara 70\%-100\% pendapatan mereka menurun akibat harga lada yang sangat murah saat ini.

Sementara itu dari sisi masyarakat yang bekerja sebagai honorer dan PNS, mereka juga ikut merasakan kondisi ekonomi yang tidak stabil pada saat ini tetapi persentase penurunan pendapatan mereka tidak terlalu besar dibandingkan dengan petani dan pedagang di Desa Bencah. Mereka hanya mersakan penurunan harga lada saat ini berdampak sebesar kisaran 20\%-40\% terhadap kondisi pendapatan mereka. Hal ini tentunya disebabkan oleh gaji seorang PNS yang tetap dan dibayar oleh Pemerintah sedangkan bagi honorer kendalanya adalah keterlambatan pencairan gaji mereka akibat kondisi ekonomi yang tidak stabil.

Kondisi penurunan harga lada saat ini yang turun dratis dan dianggap merugikan bagi petani menyebabkan sebagian dari petani untuk berkeinginan beralih ke pekerjaan lainnya. Jika dahulu pendapatannya itu murni dari hasil penjualan lada saja, tetapi sekarang masyarakat sudah banyak yang beralih ke pekerjaan lainnya walupun hanya sebagai pekerjaan sampingan, misalnya menjadi penyadap karet, kuli bangunan dan pekerjaan lainnya.

Faktor-faktor penurunan harga Bangka Belitung disebabkan oleh banyak faktor. Salah satu faktor yang menjadi penyebab harga lada turun adalah kualitas lada itu sendiri. Banyak petani yang tidak tahu bagaimana cara pengolahan budidaya lada yang baik. Berdasarkan data penelitian sebesar 53,1\% masyarakat Desa Bencah setuju bahwa penggunaan pestisida yang berlebihan serta penggunaan pupuk kimia menjadi salah satu penyebab penurunan kualitas lada itu sendiri sehingga berdampak pada penurunan harga lada yang dianggap kalah bersaing dengan kualitas lada ekspor dari Negara lainnya seperti Negara Vietnam. Padahal kondisi Kurs Asing pada saat ini mengalami kenaikan, seharusnya sesuai dengan hukum ekonomi harga lada pun harus meningkat atau paling tidak stabil dari harga sebelumnya.

Berdasarkan permasalahan penurunan harga lada saat ini, pemerintah Bangka Belitung sudah menyiapkan solusi untuk mengatasi masalah tersebut yaitu dengan menerapakan kebijakan Resi Gudang Lada yang diatur dalam UU NO. 9 tahun 2006 dimana Resi gudang adalah bukti kepemilikan atas barang yang disimpan di gudang yang diterbitkan oleh pengelola gudang. Dengan sistem resi gudang lada, petani dapat pembayaran dari jaminan lada yang dititipkan. Petani mendapat harga lada dengan harga yang telah disepakati saat penitipan awal serta total selisih lada yang ditetapkan saat penitipan awal.

Menurut Gubernur Bangka Belitung, program system resi gudang lada mampu menjaga stabilitas harga lada dan pemasaran lada ke dunia secara global kemudian kualita lada Babel pun diperhatikan dengan pembersihan bakteri lada. Akibatnya, lada Babel akan menjadi lada terbaik dunia ditengah-tengah persaingan ketat dari beberapa Negara penghasil lada lainnya. Program ini diiringi dengan pendampingan petani tentang bagaimana cara berkebun yang baik, pemberian bantuan bibit unggul, mendirikan pusat penelitian dan pengembangan lada nasional di UPT Pembibitan dan Peternakan Palempang yang bekerja sama dengan Universitas Bangka Belitung dan Universitas Gajah Mada. Tujuannya agar kejayaan lada Babel akan bisa diraih lagi, kesejahteraan hidup petani naik, daya beli masyarakat tinggi sehingga roda perekonomian di bangka Belitung semakin baik.

Meskipun pihak pemerintah sudah menjalankan program resi gudang lada di wilayah Bangka, tetapi untuk Masyarakat Desa Bencah program ini masih belum terealisasikan, bahkan banyak masyarakat Desa Bencah yang belum tahu sama sekali tentang program ini terutama bagi masyarakat awam. Sementara itu, berdasarkan hasil penelitian menyatakan bahwa sebesar 65,6\% masyarakat tertarik dengan program pemerintah berupa Resi Gudang Lada sedangkan sisanya sebesar $34,4 \%$ tidak tertarik dengan program ini dikarenakan ketidaktahuan mereka tentang program tersebut. 
Jurnal Manajemen dan Bisnis MEDIA EKONOMI, Vol. XIX, No. 2 Juli 2019

\section{KESIMPULAN DAN SARAN}

Berdasarkan hasil analisa penelitian yang telah dilakukan, maka kesimpulannya adalah sebagai berikut :

1 Berdasarkan data BPS Provinsi Kepulauan Bangka Belitung, ekonomi Kepulauan Bangka Belitung tahun 2018 tumbuh sebesar 4,45\% dan menurun sebesar 0,02\% jika dibandingkan dengan tahun 2017 yaitu sebesar 4,47\%. Hal ini disebabkan oleh penurunan pendapatan masyarakat karena harga lada turun.

2 Penurunan harga lada yang drastis saat ini dirasakan oleh masyarakat Desa Bencah Kabupaten Bangka Selatan Provinsi Kepulauan Bangka Belitung. Dari data hasil penelitian menunjukan bahwa sebesar 96,4\% masyarakat Desa Bencah merasakan dampak dari penurunan harga lada ikut mempengaruhi kondisi pendapatan mereka.

3 Petani Desa Bencah menyatakan bahwa pendapatan mereka menurun dalam kisaran antara $70 \%-100 \%$ akibat dampak dari penurunan harga lada. Sementara bagi masyarakat yang bekerja sebagai wiraswasta pendapatannya ikut menurun dalam kisaran 40\%-70\%, sedangkan bagi masyarakat yang bekerja sebagai PNS dan honerer penurunan pendapatan mereka berkisar antara 20\%-40\%.

4 Faktor yang mempengaruhi penurunan harga lada Babel disebabkan banyak hal, salah satunya adalah penurunan kualitas lada Babel akibat penggunaan pestisida yang berlebihan dan penggunaan pupuk kimia. Berdasarkan data penelitian sebesar 53,4\% masyarakat Desa Bencah menyatakan setuju jika penggunaan pestida dan pupuk kimia yang berlebihan berdampak pada harga lada di dunia.

5 Program resi gudang lada adalah program yang diterapkan sebagai solusi untuk mengatasi masalah penurunan harga lada. Dengan sistem resi gudang lada, petani mendapat harga lada dengan harga yang telah disepakati saat penitipan awal serta total selisih lada yang ditetapkan saat penitipan awal. program ini sangat bermanfaat bagi masyarakat Desa Bencah untuk memajukan roda perekonomian masyarakat desa itu sendiri maupun bagi pemerintah setempat tetapi program ini masih belum terealisasikan dengan baik di Desa Bencah .

\section{DAFTAR PUSTAKA}

Tim Karya Tani Mandiri, 2017. Rahasia Sukses Bertanam Lada. Penerbit Nuansa Aulia.

Sumiyanti, 2019. Kondisi pertumbuhan ekonomi .dikutippada tanggal 2 Maret 2019 dari https:/babel.bps.go.id. 